\title{
EFFECT OF VALVE TIMING AND EXHAUST BACK PRESSURE ON THE PERFORMANCE OF GASOLINE ENGINE BY
}

\author{
S. M. Rabia and M. Abd-EI-Halim \\ * Power and Energy Engineering Dept. Faculty of Engineering, \\ El-Minia University \\ ** Mechanical power Dept. Faculty of Industrial Education, \\ Suez Canal University
}

(Received February 20, 2010 Accepted March 21, 2010).

Today, studying the parameters that affected on the gasoline engine performance becomes very important for the popular using of this type of engines. In spite of the previous studies concerning the economic fuel consumption, some aspects still need more investigations. There are many investigations concerning the internal combustion engine performance. In previous researches the effect of valve timing on engine performance and detonation were studied. In this work, the effect of changing exhaust back pressure with variable intake valve timing on the engine performance was theoretically studied. It was found that the fuel consumption decreased and engine performance improved. The validity of the simulation technique was checked by comparing its results with those from experimental results then a good agreement was noticed.

KEY WARDS: efficiency, volumetric efficiency, specific fuel combustion, valve timing

\begin{tabular}{|c|c|c|c|}
\hline \multicolumn{4}{|c|}{ Nomenclature } \\
\hline $\begin{array}{l}\text { IVC } \\
\text { ISFC }\end{array}$ & $\begin{array}{l}\text { intake valve closing, degree } \\
\text { improved specific fuel }\end{array}$ & & $\begin{array}{l}\text { after bottom dead centre, } \\
\text { degree }\end{array}$ \\
\hline & consumption, $\mathrm{kg} / \mathrm{kW} . \mathrm{h}$ & $\mathrm{BDC}$ & Bottom dead center, degree \\
\hline LIVC & Late intake valve closing, & $\mathrm{CA}$ & crank angle degree, degree \\
\hline & degree Pressure bar & EBP & engine back pressure, bar \\
\hline TDC & $\begin{array}{l}\text { top dead center, degree } \\
\text { Volume } \mathrm{m}^{3}\end{array}$ & EIVC & $\begin{array}{l}\text { early intake valve closing, } \\
\text { degree }\end{array}$ \\
\hline
\end{tabular}

\section{INTRODUCTION}

In the conventional gasoline engines, there is some power loss arise during suction stroke and exhaust stroke. This loss is pumping loss. It is graphically evaluated as the area between inlet and exhaust pressure curve on p-v diagram. This area increases with decreasing engine load. That is because the cylinder inlet pressure decreases with decreasing engine load (part throttle). This will reduce the brake thermal efficiency, which change from maximum at full throttle to zero at idling. 
To reduce this loss at part load, one alternative technique was used in the previous study. The idea of this technique is to control the engine load by changing the inlet valve timing instead of using throttling value. That means controlling the quantity of fresh charge entering into the cylinder. It can be achieved by late or early intake valve closing (LIVC or EIVC). In LIVC, some charge is pumped back into the inlet manifold after bottom dead centre (ABDC), or the introduction process is to be stored by EIVC.

The cylinder pressure in exhaust blow down stroke is about atmospheric. The reduction in this pressure will be affecting the residual gas and volumetric efficiency. It is well known that the residual gas left in the clearance volume has direct effects on the combustion. The increase of the residual gas will reduce the combustion efficiency. Also, the volumetric efficiency will decrease, which in this case reduce the engine performance. The residual gas increases with decreasing engine load that is due to the big difference between inlet and exhaust manifold pressures.

The two effects, residual gas and pumping losses, will cause a great reduction in the engine performance.

In an attempt to improve the engine performance Luria [1] found that late intake valve closing control offer advantage in the engine performance.

By using detailed computer simulation of both single and multi cylinder engine Saunders [2] has shown that inlet manifold pulsation can be diminished with LIVC, when charge is pumped back before IVC. The possibility of more uniform distribution between cylinders of both residual gases and $\mathrm{A} / \mathrm{F}$ ratio are also implied. A test bed results was achieved by Tuttle [3] for a single cylinder both with throttle and LIVC. He has reported that there is no improvement in fuel consumption with LIVC.

By using four cylinders, four stroke petrol engine, Saunders and Rabia [4] have shown that the LIVC technique achieves improvement in fuel consumption at part load with a maximum gain of $11 \%$ at about half load.

The reduction in the engine exhaust back pressure (EBP) is the other idea used to improve the petrol engine performance. This idea has great influence on the residual gases and consequently on the volumetric efficiency as well as the thermal efficiency.

Saadawi, Ibrahim and Moghazy [5] have theoretical and experimental investigation on the influence of lowering the exhaust back pressure on the combustion process, and the performance of a single cylinder spark ignition engine. They found, that the decreasing in exhaust back pressure will decrease the residual gas trapped in the cylinder and increase mean effective pressure. Also the volumetric efficiency increases as the exhaust back pressure is reduced.

There are recent researches were done concerned the gasoline engine performance. Kang and Grizzle [6] performed an experimental work on engines equipped with a means to actuate air flow at the intake valve can achieve superior fuel economy performance in steady state. They research work shows how modern nonlinear design techniques can be used to control such an engine over a wide range of dynamic conditions. The problem is challenging due to the nonlinearities and delays inherent in the engine model, and the constraint on the air flow actuator. The controller is designed on the basis of a mean-value model, which is derived from a detailed intake stroke model. The control solution has two novel features. Firstly, a recovery scheme for integrator wind-up due to input constraints is directly integrated into the nonlinear control design. The second novel feature is that the control Lyapunov function 
methodology is applied to a discrete-time model. The performance of the controller is evaluated and compared with a conventionally controlled engine through simulation on the detailed engine model. M. Gumus et al [7] they introduced optimization criterion to be chosen for the optimum design of the heat engines may differ depending on their purposes and working conditions. In their study, a comparative performance analysis was carried out for a reversible Otto cycle based on three alternative performance criteria namely maximum power ( $\mathrm{mp}$ ), maximum power density (mpd) and maximum efficient power (mep). The power density criterion is defined as the power per minimum specific volume in the cycle and the efficient power criterion is defined as multiplication of the power by the efficiency of the Otto cycle. They concluded that the maximizing of the efficient power gives a compromise between power and efficiency. They introduced also, three different objective functions are defined and maximization of these functions was carried out under different design parameters of the Otto engine. The variations of power, power density and efficient power outputs are derived and presented with respect to the thermal efficiency of the cycle for various temperature ratios. They found that, also the design parameters at mep conditions lead to more efficient engines than that at the $\mathrm{mp}$ condition and the mep criterion may have a significant power advantage compared with mpd criterion. E. Abu-Nada et al. [8] Performed study of several parameters are affecting on spark ignition engine performance. They used various gas mixtures as a working fluid. They obtained results which were compared with those that use air as the working fluid. The studied parameters were the equivalence ratio, engine speed, maximum and outlet temperatures, brake mean effective pressure, gas pressure, and cycle thermal efficiency. They found that it is more realistic to use gas mixture in cycle analysis instead of merely assuming air to be the working fluid, especially at high engine speed not les than $5000 \mathrm{rpm}$.

In the present work a simulation model developed by Benson et al. [9] was adjusted for a four stroke, four cylinder gasoline engines. The engine performance is tested with combination of LIVC and reduction in the EBP. The effect of these parameters on fuel saving, residual gas, and volumetric efficiency is studied. This allows a direct comparison between the performance of conventional engine, and modified engine operating at the same conditions.

\section{RESULTS AND DISCUSSION}

A comprehensive simulation package was developed by Benson et al. [9] .It is valid for one or more cylinders, and for two or four stroke engines. The program allows for including the wave action in the intake and exhaust systems in the prediction of exhaust emission. To simulate complete cycles the calculations are organized into two parts. First part is used to simulate the period between inlet valve closing and exhaust valve opening (power section). Second part starts from the exhaust valve opening and finishes with closing the inlet valve (gas exhaust section).

The results include:

1- $\quad$ Pressure and temperature distribution inside the pipes.

2- Instantaneous pressure and temperature inside the cylinder.

3- Fraction of residual gas in each cylinder.

4- Instantaneous mass flow rate entering the cylinders. 
5- Indicted mean effected pressure (IMEP) indicated thermal efficiency and the other engine performance parameters.

The engine dimension such as length and diameter of inlet and exhaust pipes, inlet and exhaust valve lift, ..etc are the invariable data added into the program. The variable data depends on the engine running condition such as:

1. Exhaust back pressure.

2. Different LIVC angles.

3. Flame factor and ignition timing.

4. Pressure losses coefficient in carburetor.

The flame speed factor and the ignition timing were adjusted by allowing the programme to run several times with different values until top dead center (TDC) is approximately in the middle of the combustion period.

Pressure losses coefficient (resistant coefficient) depends on much number, and throttle position. At full throttle, it was adjusted to give reasonable volumetric efficiency.

The unsteady flow through the pipes, inlet and exhaust values and carburetor during the engine running causes fluctuation in the trapped change in the cylinder, which causes fluctuation in the engine performance from cycle to cycle. For this reason it was necessary to run the program several cycle to establish stable condition.

Performance simulation for ten cycles has been conducted over a full and part load ranges at 3000 RPM. The mean value of these ten cycles excluding the first one was approximately the same as for the fourth cycle. The fourth cycle performance was taken in this paper results.

The engine used as a basis for this research was a gasoline engine, 1300cc, four cylinders, four stroke. Overhead rockers with push rods are the valve train. The engine details are presented in Appendix I.

The engine simulation program modified for LIVC and variable EBP, as well as conventional condition. The programme was adjusted to work at two different engine speeds; 2000, and 3000 RPM. At these two speeds the obtained results are convenient and reliable to give a good prediction of the engine performance. At lower speeds the programme needs very accurate limits specified for iteration in calculating the Riemann variable on exit from the carburetor, which uses the method of characteristic for all pipes and manifold flows. That makes the running time very long.

The EBP was adjusted to be 1.0, 0.8, 0.6, and 0.4 bar. The engine parameters were calculated for conventional and LIVC condition at each pressure. The LIVC angle was adjusted to be $45^{\circ}, 70^{\circ}$, and $90^{\circ}$ crank angle degree (CA) after conventional closing. These angles were enough to control the engine load until a very low load.

Cylinder pressure was recorded at each $20^{\circ} \mathrm{CA}$. The pressure for all cylinders was recorded but due to similarity the results of cylinder number one, and cylinder number three were considered.

The experimental results were taken for four cylinders, $1300 \mathrm{cc}$ engine was used. The engine modified to allow for controlling load by either LIVC or throttle. The program modified for the same engine dimensions and parameters.

The reliability of the simulation results was checked by comparing it with experimental results. A good agreement and reliable results were achieved.

The mixture of fuel and air was always adjusted at stoichiometric condition. 
The pressure/volume diagram in Fig. (1) shows the pumping loops for simulated and measured pressures of cylinder number one at the same volumetric efficiency. The simulation diagram LIVC is obtained at $2000 \mathrm{rpm}$ for $90^{\circ} \mathrm{CA}$, and the experimental recorded data at $92^{\circ} \mathrm{CA}$. This figure shows a good agreement between the two cases.

Throttle simulation $\left(90^{\circ} \mathrm{CA}\right)$ LIVC Experiment $\left(92^{\circ} \mathrm{CA}\right)$ IMEP 2.5 bar
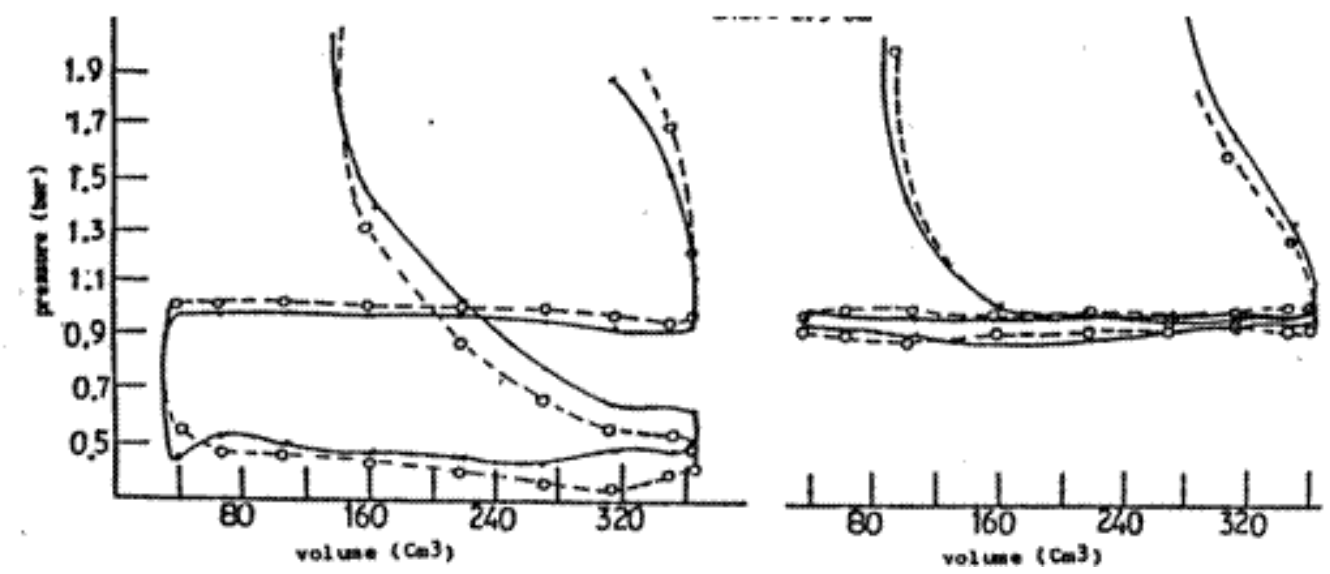

Fig. (1) Pressure / Volume Diagram at 2000 RPM

The effect of LIVC on IMEP for both simulation and experimental at 3000 RPM is shown in Fig. (2). It is shown that the simulated values vared to approach from the experimental data by measuring the engine load. This deviation may be due to the differences in the computed volumetric efficiency and ignition timing applied for calculates the IMEP of the experimental data.

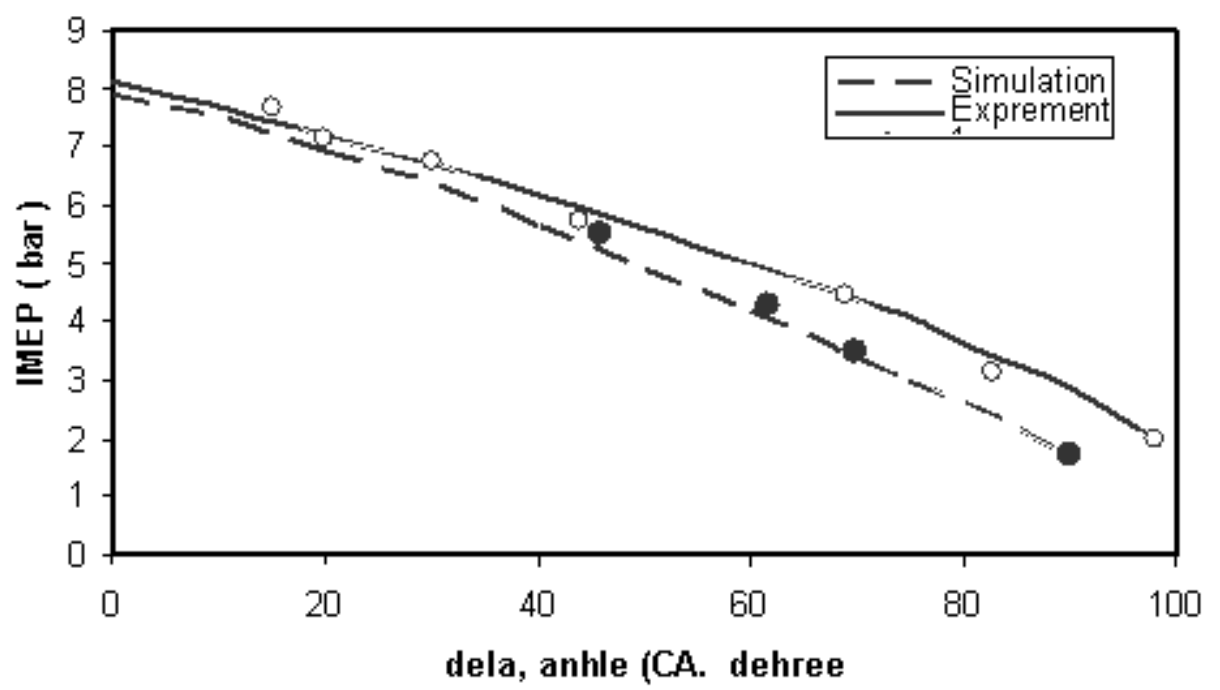

Fig. (2) LIVC Angle in the Simulation and Experiment Results N = 3000rpm 
The above results show a good agreement between experimental and simulation results; thus the simulation results in this research work can be a appreciable investigations where represent about relative values

Figures $[3,4]$ show the predicted cylinder pressure distribution during inlet and exhaust stroke for cylinder number one. It is observed that the exhaust back pressure 0.4 bar corresponds lower the cylinder inlet pressure compared with that observed at back pressure 1 bar. Lower pressure is normally expected as reducing the inlet manifold pressure.

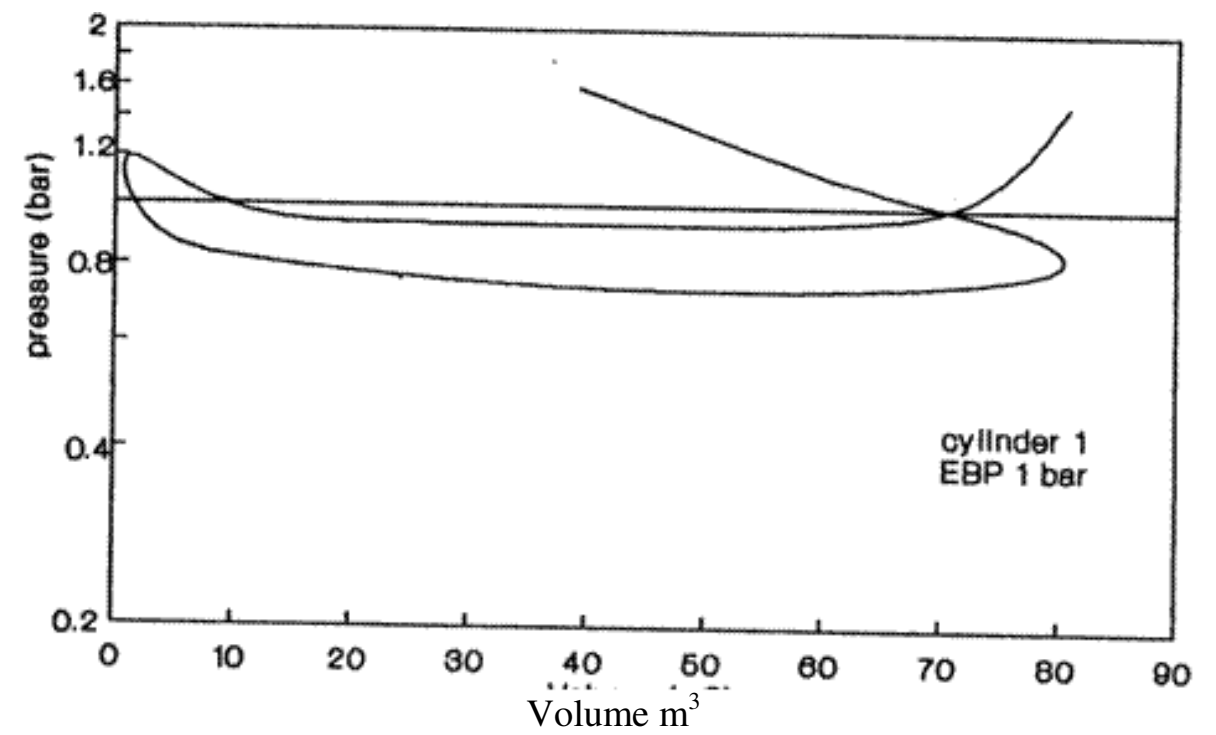

Fig. (3) Inlet and Exhaust Pressure Curve at 2000 RPM Volume $\mathrm{m}^{3}$

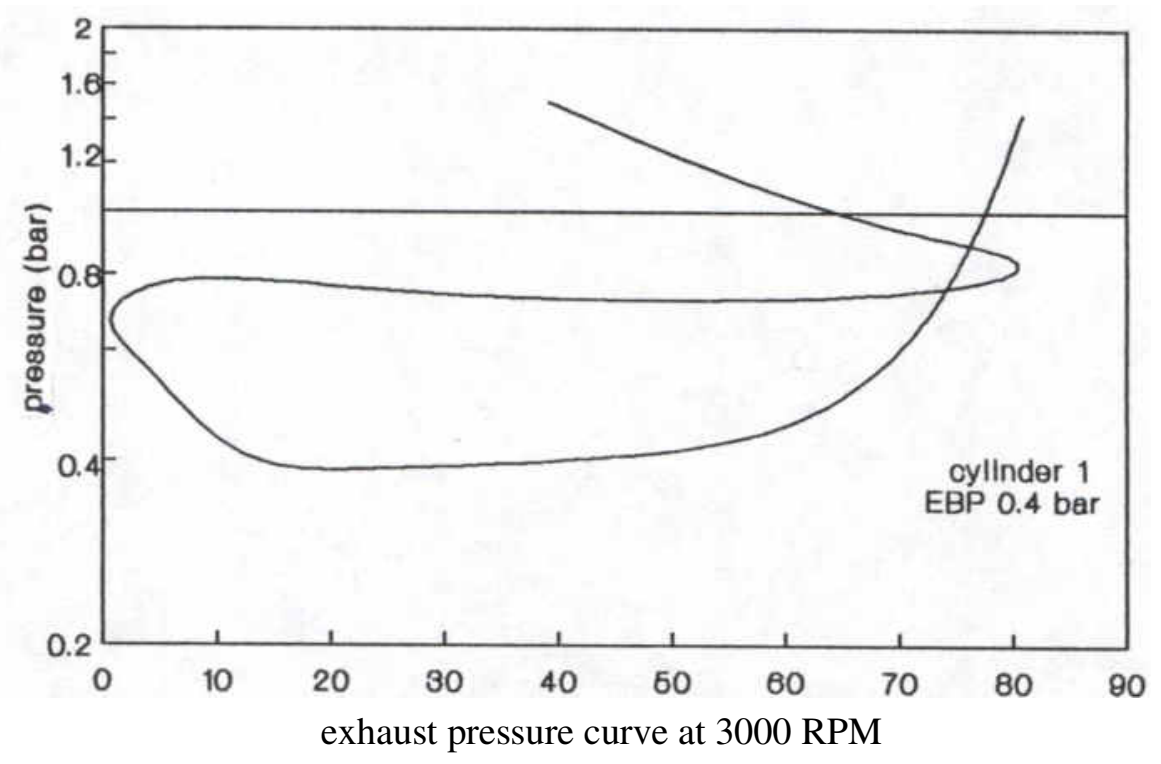

Fig. Inlet and 
Figures $(5,6)$ show the improvement in fuel consumption due to reduction in the exhaust back pressure. Load was controlled by throttling (conventional engine). The improvement increases with decreasing exhaust back pressure even at full load. Also the improvement increases with decreasing engine load. In all cases the improvement occurs due to the continuous reduction in the residual gases which in turn effects on the combustion process.

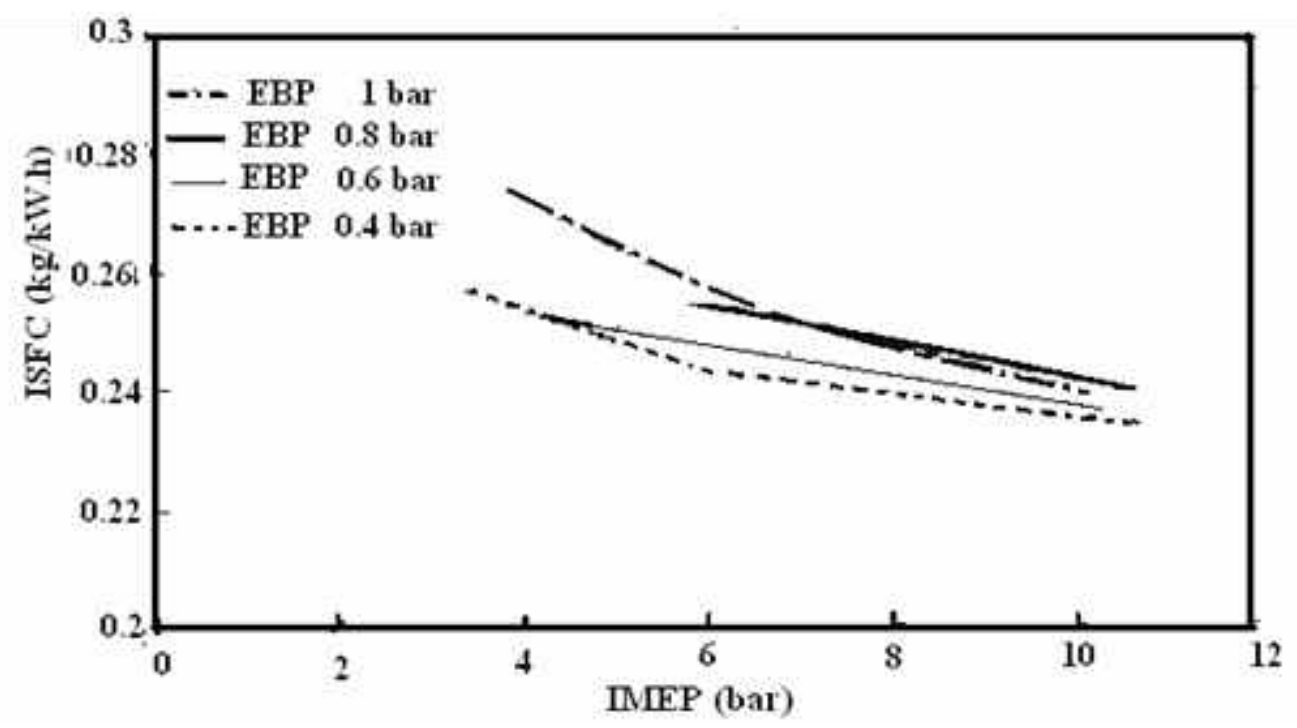

Fig. (5) ISFC the conventional engine speed at 2000 RPM

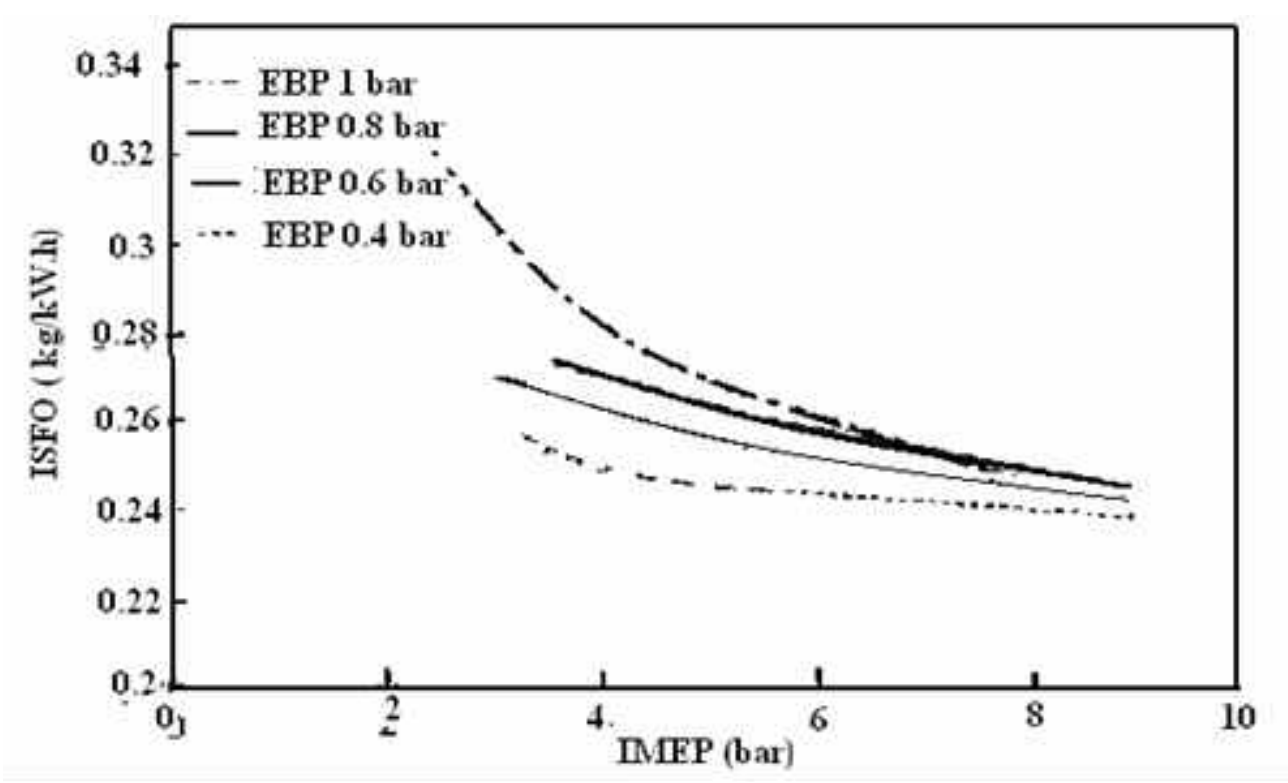

Fig. (6) ISFO for the Conventional Engine speed at 3000 RPM 
The maximum improvement in ISFC is $6.4 \%$ at $60 \%$ of the maximum load and 2000 RPM. At 3000 RPM the maximum improvement was $12 \%$ at $43 \%$ of the maximum load.

Figures $(7,8)$ show the relation between IMEP and ISFC at 2000 and 3000 RPM. It is very clear that there is an improvement in fuel consumption at different EBP. In these two figures, and at full load, there is no difference between control engine load by throttling and by LIVC so the ISFC should be the same. At back pressure 0.8 bar and full throttle there is no improvement, that may be because the pressures during inlet and exhaust strokes are identical.

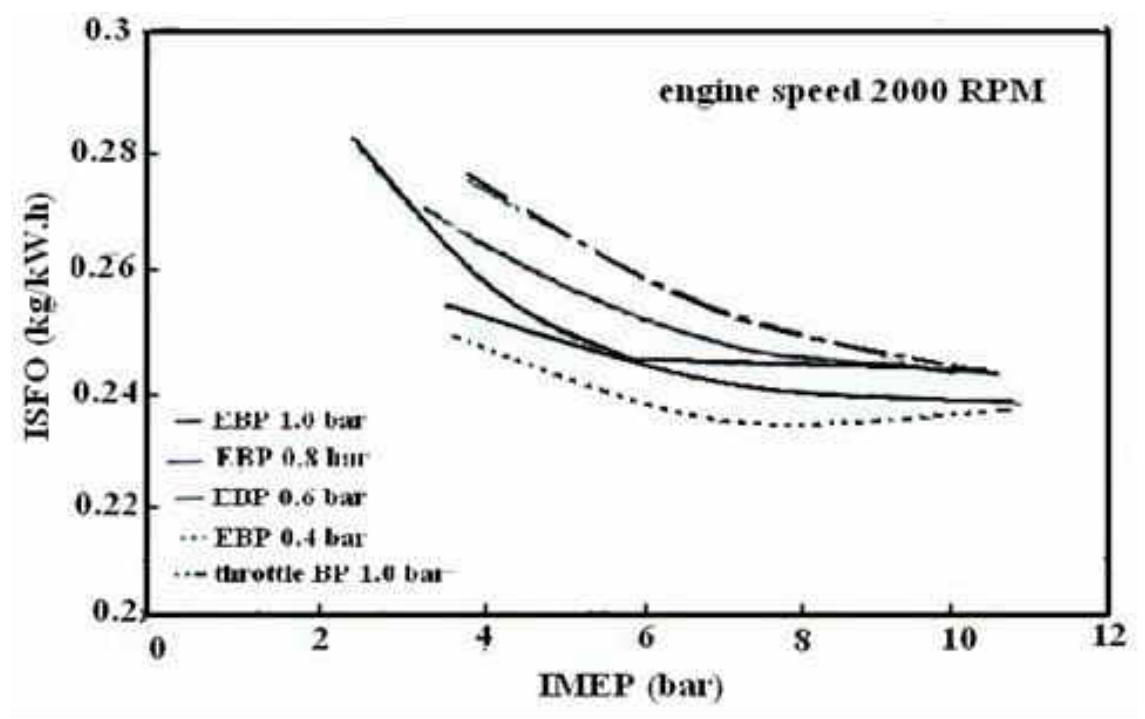

Fig. (7) ISFC at Different Exhaust Back Pressure

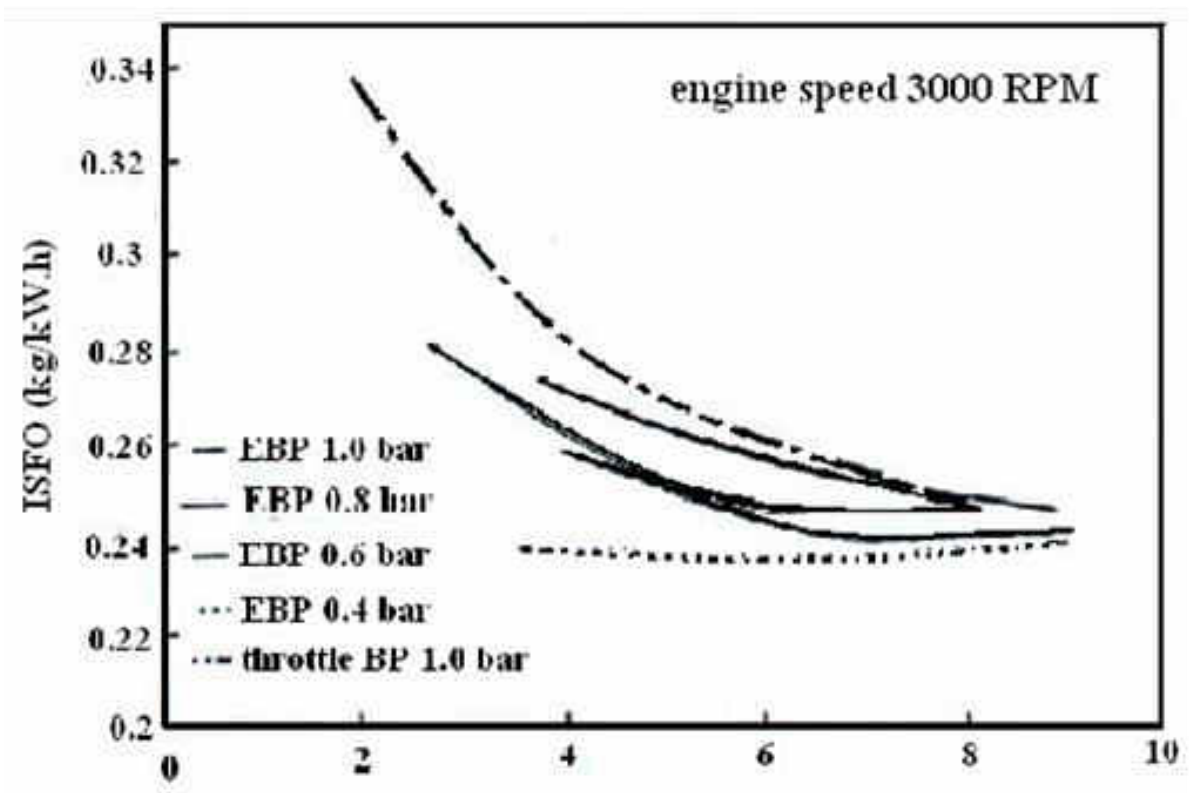

Fig. (8) ISFC at Different Exhaust Back Pressure. 
At EBP less than 0.8 bar there is small improvement in ISFC, which may be because the exhaust pressure becomes lower than the intake pressure. Also, the residual gas trapped in the cylinders is reduced.

At part load and EBP 1 bar there is a large improvement in fuel consumption due to LIVC. The maximum value of this improvement is $9 \%$ at IMEP 4.34 bar and for engine speed 2000 RPM, and is 10\% at IMEP 2.76 bar for engine speed 3000 RPM.

More economic in fuel consumption is occurred if the EBP is decreased less than 0.6 bar, that is for all engine loads and different speeds. It becomes $10.5 \%$ at $73 \%$ of the maximum load, that if compared with the conventional engine at EBP 1 bar and 2000 RPM. At 3000 RPM is $15 \%$ at $48 \%$ of the maximum load.

The aim of using LIVC as load control is to reduce the pumping losses at part load, which in this case keep the inlet manifold pressure in the range of 1 to 0.8 bar as same as full throttle. In this case some of the fresh charge is blow back into the inlet manifold. This fresh charge has some of residual gas. It will be mixed with fresh charge sucked into the next cylinder. This routine may be gives no good homogeneous mixture, that is because there is some reduction of pulsation in the inlet manifold. On the other hand the mixing between fresh charge and high temperature residual gas will achieve some improvement in this mixture. The worst case expected is that at very low load is believed some of fresh charge blow back again across the carburetor in the opposite direction then suck into the cylinder across the carburetor again. In this case the thermal efficiency is reduced because rich mixture is achieved

EBP was the tool which was used to control the residual gas mixed with fresh charge .Also, it is believed that some improvement happens in the pulsation of the flow inside the cylinder and inlet manifold due to the reduction in the EBP. Thus, more improvement in the engine performance was achieved at EBP less than 0.6 bar with controlling engine by LIVC.

The volumetric efficiency at different loads and exhaust back pressers are shown in Figs $(9,10)$. It is very clear that the volumetric efficiency decreases with decreasing exhaust back pressure to give the same IMEP. The result of this, the indicated thermal efficiency will be increased.

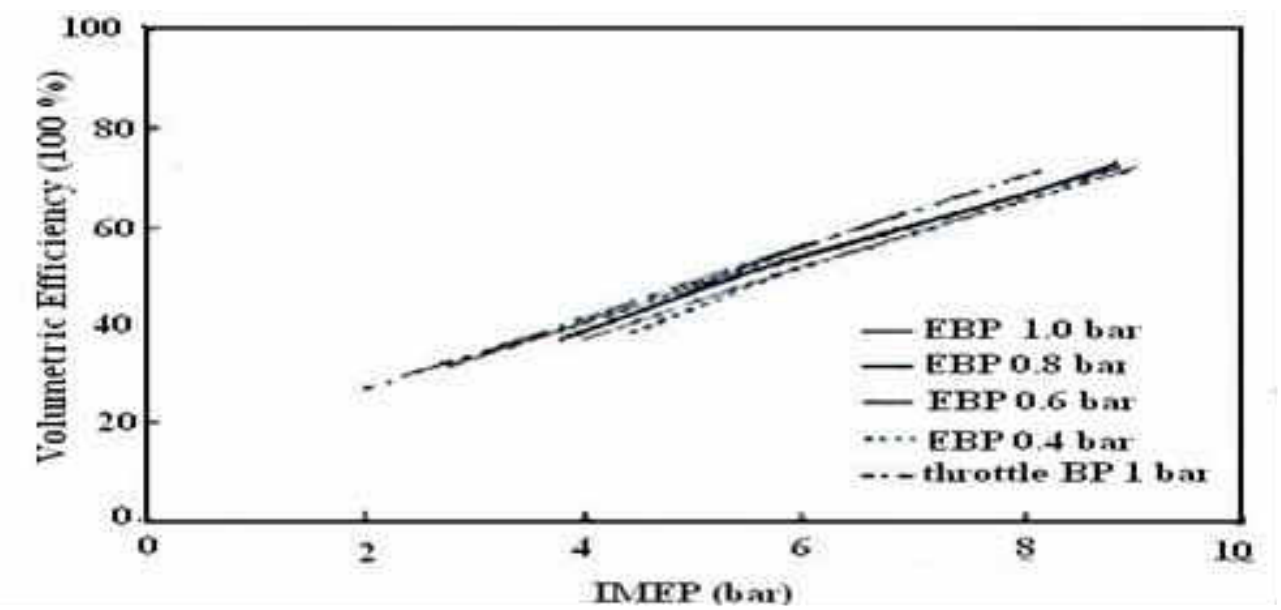

Fig. (9) Volumetric Efficiency at 2000 RPM 


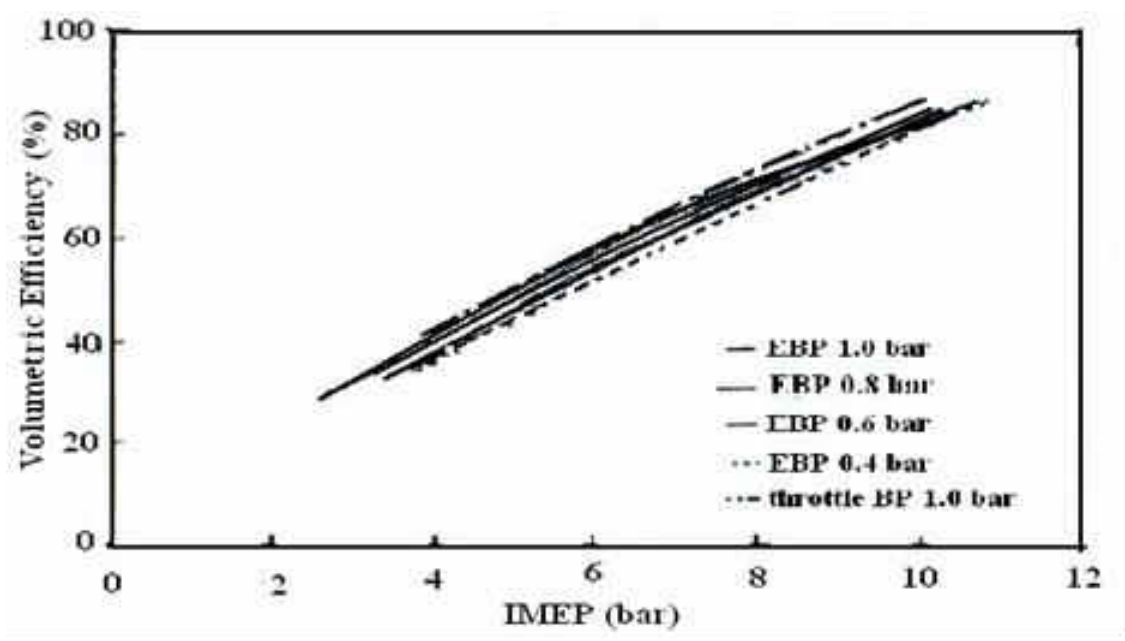

Fig. (10) Volumetric Efficiency at 3000 RPM

The maximum pressure inside the cylinder at different loads is shown in Figs. $(11,12)$, which show no big difference between curves at the same load.

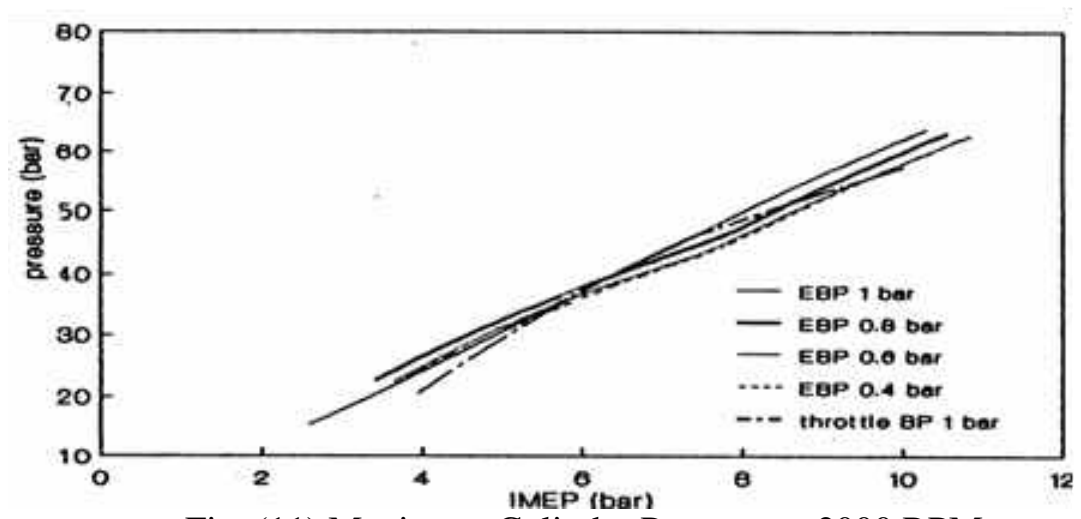

Fig. (11) Maximum Cylinder Pressure at 2000 RPM

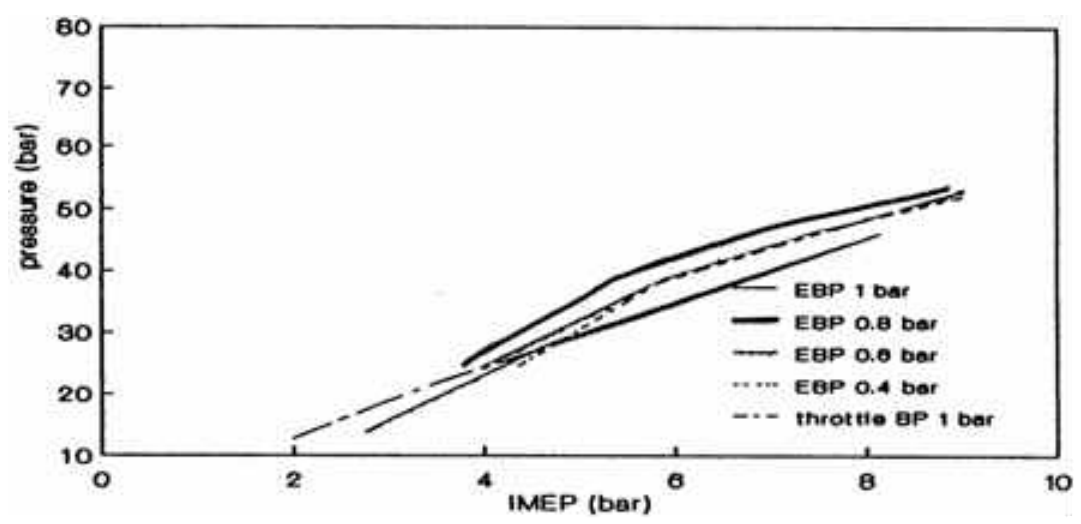

Fig. (12) Maximum Cylinder Pressure at 3000 RPM 


\section{CONCLUSION}

This paper investigated theoretically the effect of valve timing and exhaust back pressure on the performance of gasoline engine. The engine performance was tested with combination of LIVC and reduction in the EBP. The effect of these parameters on fuel saving, residual gas, and volumetric efficiency was studied. The main concluded items are as follows:

1- Reduction in the fuel consumption due to the reduction in exhaust back pressure in the conventional engine.

2- The combination between LIVC and reduction of exhaust back pressure less than 0.6 bar gives more improvement of engine performance by about $15 \%$ of fuel consumption could be saved.

3- As expected, the engine volumetric efficiency increased due to reduction of exhaust back pressure.

4- The maximum pressure inside the cylinder at different loads shows low differences at the same load.

5- The validity of the simulation technique was checked by comparing its results with those from experimental results and a fair agreement was noted.

\section{REFERENCES}

1. LURIA D., TAITEL Y., and STOTTER, A., "The Otto - Atkinson Engine anew Concept in Automotive Economy, SAE paper 820352, 1982.

2. SAUNDERS R.J., "Atkinson Cycle Spark Ignition Engine," Int. j. of vehicle Design, IAVD Congress on Vehicle Design and Components. 1984.

3. TUTTLE J.H., "Controlling Engine Load by Means of Late Intake Valve Closing," SAE paper, 800794, 1980.

4. SAUNDERS, R.J., and RABIA, S.M., "Part Load Efficiency in Gasoline Engines," paper presented at Institution of Mechanical Engineers, Combustion Engines Group, 1986.

5. SAADAWI, M.H., IBRAHIM, A.M., and MOUGHAZY, I.M., "The Effect of Exhaust Back Pressure on the Combustion and Performance Characteristics of Ignition Engines," Bulletin of the Faculty of Engineering, University of Assuit, 1984.

6- Kang, J.Mo. and Grizzle, J.W. " Dynamic control of a SI engine with variable intake valve timing", International Journal of Robust and Nonlinear, Control Volume 13, Issue 5, Pages: 399-420, April 2003.

7- Gumus, M., Atmaca, M. and Yilmaz, T. , " Efficiency of an Otto engine under alternative power optimizations" International Journal of Energy Research, Volume 33, pp. 745-752, Jan. 2009.

8- Abu-Nada, E., Al-Hinti, I., Akash, B., and Al-Sarkhi, A., "Thermodynamic analysis of spark-ignition engine using a gas mixture model for the working fluid, International Journal of Energy Research Volume 31, Issue 11, pp. 1031-1046 Jan. 2007.

9. BENSON, R.S., ANNAND, J. D. and BARUAH, P.C., "A simulation Model Including Intake and Exhaust Systems for a Single Cylinder Four-Stroke Cycle 
Spark Ignition Engine," Int. J. Mech. Sci, Pergamon Press, vol.17, PP. 97-124, 1975.

\section{APPENDIX I}

The specifications of the engine are:

Number of cylinders

Bore

Stroke

Crank length

Combustion chamber volume

Standard compression ratio

Valve timing is:

IVO

IVC

EVO

EVC
4 in line

$71.1 \mathrm{~mm}$

$81.28 \mathrm{~mm}$

$165.55 \mathrm{~mm}$

$142 \mathrm{cc}$

8.6

5 CA BTDC

$45 \mathrm{CA} A B D C$

$51 \mathrm{CA} B \mathrm{BBDC}$

$21 \mathrm{CA}$ ATDC

\section{تأثير توقيت فتح صمام العادم و الضغط الخلفى على آداء محرك النزين}

اصبحت دراسـة المتغيرات التى تؤثر على اداء محركات البنزين فى مكان من الاهميـة القصوى نظـرا لرواج هذا النوع من المحركات فى مجالات عديدة من الحياة. بالرغم من ان الدراسات والابحاث السابقة المتعلقة بالاستهلاك الاقتصادى للوقود وتحسين اداء محركات البنزين عديدة و متتوعة الا انها مازالت تحتاج الى بعض الدراسات الاخرى. فى هذا البحث تم عمل دراسـة نظريـة لدراسة تأثير تأثير الضغط الخلفى مـع تغير توقيت فتح صمام العادم للاسطوانة. لقد وجد تأثثر هذه الظاهرة تأثنيرا واصحا على هـ

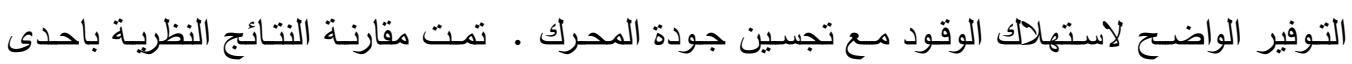
الدراسـات السبقة من خـلال احدى برامح المحاكاة بالحاسب والتى وجدت انها تتوافق نوافق جيد مـع لـع النتائج العملية وذللك من خلال منحنات قياس الآداء. 